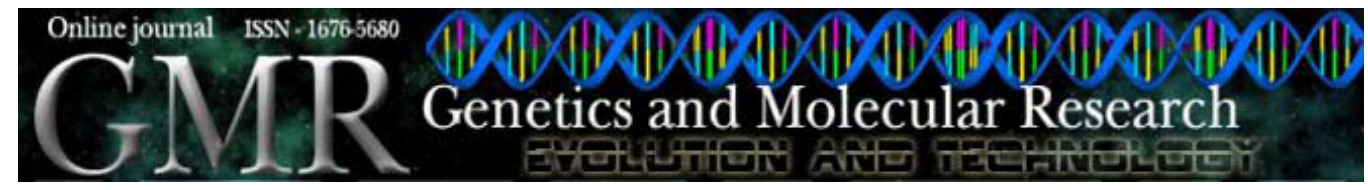

Methodology

\title{
Simple and efficient method for isolating cDNA fragments of lea3 genes with potential for wide application in the grasses (Poaceae)
}

\author{
L. Yu, X. Wu, X. Tang and B. Yan \\ Faculty of Landscape Architecture, Southwest Forestry College, \\ Kunming, China \\ Corresponding author: B. Yan \\ E-mail: yanbodr@yahoo.com.cn
}

Genet. Mol. Res. 9 (3): 1321-1325 (2010)

Received March 15, 2010

Accepted May 15, 2010

Published July 6, 2010

DOI 10.4238/vol9-3gmr852

\begin{abstract}
DNA fragments of lea 3 genes with a high GC content (from 68 to 77\%) were found in several Poaceae, including Sorghum vulgare, Saccharum officinarum, Oryza officinalis, Oryza meyeriana, Ampelocalamus calcareus, Cynodon dactylon, and Zizania latifoli. They were successfully isolated by means of optimal experimental parameters, which included dimethyl sulfoxide as additive and degenerate primers "AGETKAS" and "AGKDKTG", and their sequences were analyzed. Compared to the method of isolating genes by screening of a cDNA library using abscisic acid- and other stressresponsive cDNA clones, which is time-consuming and costly, this method is relatively easy and inexpensive. Using this new method, many new homologue lea 3 genes were rapidly determined.
\end{abstract}

Key words: Gramineae plants; lea3 gene; High GC content sequence; Degenerate primers 


\section{INTRODUCTION}

Late embryogenesis abundant (LEA) proteins are mainly low-molecular weight (10-30 $\mathrm{kDa}$ ) proteins, that are involved in protecting higher plants from damage caused by environmental stress especially drought. Based on their amino acid sequences, LEA proteins are basically divided into five groups (Dure, 1993; Zhang and Zhao, 2003). To date, there have been some reports about the lea 3 gene, while its mechanism of function in plants has not been clearly revealed. Therefore, it is necessary to isolate more lea 3 genes to provide a reference for their structural and functional research. Unlike most of eukaryotic genes, which contain GC-rich sequences mainly in the promoter region, the GC content of lea 3 gene is higher in all the coding region.

A variety of polymerase chain reaction (PCR) additives and enhancing reagents have been used to increase the yield, specificity and consistency of PCR. It has been reported that some reagents such as tetramethylammonium chloride, DMSO, betaine, non-ionic detergents, and formamide are capable of improving the efficiency and specificity of PCR (Weissensteiner and Lanchbury, 1996; Kovarova and Draber, 2000). Recently, it was found that PCR could be dramatically enhanced by Au nanoparticles (Li et al., 2005). In this research, DMSO, formamide, glycerol, NP-40 (Nonidet P 40) and Tween 20 were investigated in order to determine which additive could effectively enhance the amplification of the lea 3 gene. By means of the degenerate primers designed, fragments of lea 3 genes from several species in the Gramineae were isolated by PCR with appropriate additives.

\section{MATERIAL AND METHODS}

\section{Plant materials}

Fresh seedlings from Saccharum officinarum, Oryza officinalis, Ampelocalamus calcareus, Cynodon dactylon, and Zizania latifoli were obtained from the surrounding area of Kunming. After harvesting, the whole fresh seedlings or cuttings were kept at room temperature for $4 \mathrm{~h}$ for RNA extraction. Hordeum vulgare and Sorghum vulgare seeds were soaked in water for $12 \mathrm{~h}$ and transferred to three layers of filter paper with water for 3 days under light. Germinated seedlings were air-dried for $4 \mathrm{~h}$ at room temperature for RNA extraction.

\section{Design of degenerate primers}

The sequences of lea3 genes of Hordeum vulgare (GenBank ID: X13498), Oryza sativa (GenBank ID: OSU57641, RICWSI18), Triticum aestivum (GenBank ID: AY148492, X56882), Zea mays (GenBank ID: BT023964, DQ244556, DQ246069, EU955058, NM-001111828), and Bromus inermis (GenBank ID: AB181485, AB181486) were analyzed by DNAMAN (Figure 1) for primer designing. Degenerate primers were designed as follows: forward, 5'-gccggcgagRc caaggSMc-3' (R: g/a, S: c/g, M: c/a); reverse, 5'-gScggWYttgtccttgccgg-3' (S: c/g, W: a/t, Y: c/t).

\section{RNA extraction and synthesis of cDNA}

RNA was extracted from plant tissues using the RNAsimple Total RNA kit (Tiangen, Beijing, China). First-strand cDNA synthesis was carried out using the First-Strand RT-PCR kit (TaKaRa, Dalian, China). PCR was carried out using the plant material cDNA samples described above. 


\section{RT-PCR and sequence analysis}

Amplification reactions were carried out under the following conditions: $10 \mathrm{mM}$ Tris$\mathrm{HCl}, \mathrm{pH} 8.8,50 \mathrm{mM} \mathrm{KCl}, 1.5 \mathrm{mM} \mathrm{MgCl}, 0.2 \mu \mathrm{M}$ primers, $0.01 \mu \mathrm{g} / \mu \mathrm{L}$ template, $0.2 \mathrm{mM}$ each $\mathrm{dNTP}, 8 \%$ DMSO, and $0.05 \mathrm{U} / \mu \mathrm{L}$ Taq polymerase (TransGen, Beijing, China). The cycling conditions in a Biometer ${ }^{\circledR} \mathrm{T}$ Gradient thermal cycler consisted of an initial incubation for $5 \mathrm{~min}$ at $94^{\circ} \mathrm{C}$ followed by 35 cycles each of $30 \mathrm{~s}$ of denaturation at $94^{\circ} \mathrm{C}$ and $30 \mathrm{~s}$ of annealing at $53^{\circ} \mathrm{C}$ and for $50 \mathrm{~s}$ of extension at $72^{\circ} \mathrm{C}$, along with a final elongation step at $72{ }^{\circ} \mathrm{C}$ for $7 \mathrm{~min}$. Amplified materials were subjected to electrophoresis on a $1 \%$ agarose gel stained with ethidium bromide, visualized on a UVP Imaging System and documented by VisionWorksLS. Recovery of the amplified fragment was conducted according to manufacturer instructions for the Gel Extraction Mini Kit (Huashun, Shanghai, China). The purified PCR products were cloned into plasmid vector pMD18-T (TaKaRa, Dalian, China). By DNA transformation techniques, transformed susceptibility cells were cultured on a $50-\mathrm{mg} / \mathrm{L}$ ampicillin plate for $9-16 \mathrm{~h}$ at $37^{\circ} \mathrm{C}$. After single-clone amplification in LB, harvested product was used for sequence analysis by Shanghai Shenggong Biotechnique Company, Ltd. The deduced amino acid sequences were determined by DNAMAN.

\section{RESULTS AND DISCUSSION}

\section{Optimization of experimental parameters}

The amplification of the barley HVA1 gene was carried out in order to determine which additive is efficient for isolating the lea 3 gene. The results showed that it was very difficult to amplify the lea 3 gene using genomic DNA of barley as template without any additive. DMSO at a concentration of 3 to $15 \%$ improved the yields. This finding was similar to that of Bookstein et al. (1990), while the product could be tested even when the concentration of DMSO was increased up to $15 \%$. It was different from other results of previous reports (Saiki et al., 1990; Kawasaki, 1990), showing that the product was less when formamide concentration was increased from 1 to $3 \%$ in PCR and that glycerol and non-ionic detergents such as NP-40 and Tween20 did not work effectively. Among the combinations of DMSO and glycerol at different concentrations, it was found that only the combination of $1 \%$ glycerol and 5\% DMSO could increase the product yield slightly, and that others could not improve the amplification of the lea3 gene (Figure 1).

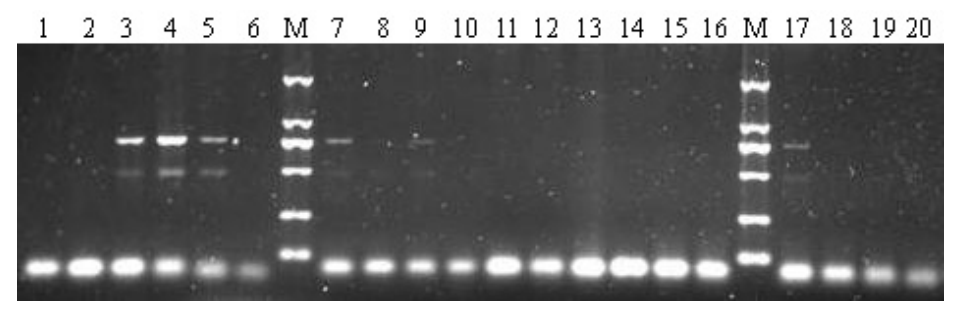

Figure 1. The effects of different additives on PCR. M = DL2000 marker; lane $1=$ no additive as control; lane $2=$ $2 \%$ DMSO; lane $3=5 \%$ DMSO; lane $4=10 \%$ DMSO; lane $5=15 \%$ DMSO; lane $6=20 \% \mathrm{DMSO}$; lane $7=1 \%$ formamide; lane $8=2 \%$ formamide; lane $9=3 \%$ formamide; lane $10=1 \%$ glycerol; lane $11=3 \%$ glycerol; lane $12=5 \%$ glycerol; lane $13=0.2 \%$ Tween 20 ; lane $14=0.8 \%$ Tween $20 ;$ lane $15=0.2 \%$ NP-40; lane $16=0.8 \% \mathrm{NP}-$ 40; lane $17=$ combination of $1 \%$ glycerol and $5 \%$ DMSO; lane $18=$ combination of $2 \%$ glycerol and $5 \%$ DMSO; lane $19=$ combination of $1 \%$ glycerol and $10 \%$ DMSO; lane $20=$ combination of $2 \%$ glycerol and $10 \%$ DMSO. 


\section{Structural analysis of lea3 gene cDNA fragments}

Under optimal conditions, fragments of lea 3 genes from some other species in the Gramineae such as $H$. vulgare, A. calcareus, $S$. vulgare, S. officinarum, O. officinalis, $C$. dactylon and $Z$. latifoli have been attained by means of the degenerate primers designed, and their sequences were analyzed. Each of their nucleotide sequences and their coding amino acid numbers were different, $S$. vulgare coded for 139 amino acids, S. officinarum for 128 amino acids, $O$. officinalis for 117 amino acids, O. meyeriana for 133 amino acids, A. calcareus for 145 amino acids, C. dactylon for 113 amino acids, and Z. latifoli for 100 amino acids. Their coding amino acid sequences were analyzed, and the alignment result (Figure 2) showed that they contained several LEA consensus sequences as reported previously (Dure, 1993). Furthermore, besides known 11-amino acid motifs in lea3 proteins, it is interesting that the amino acid sequences deduced from the degenerate primer sequences, which are composed of "AGETKAS" and "AGKDKTG", respectively, are also conserved in the Gramineae. Therefore, it could be suggested that partial cDNA fragments of lea 3 genes even in all Gramineae plants could be amplified simply by PCR using the degenerate primers. Actually, based on these fragments, full-length cDNA sequences of lea 3 genes from $S$. vulgare, A. calcareus and Z. latifoli were obtained successfully by 3' RACE and 5' RACE, for which Genbank accession numbers are GQ494000, GU433601 and GQ494017, respectively.
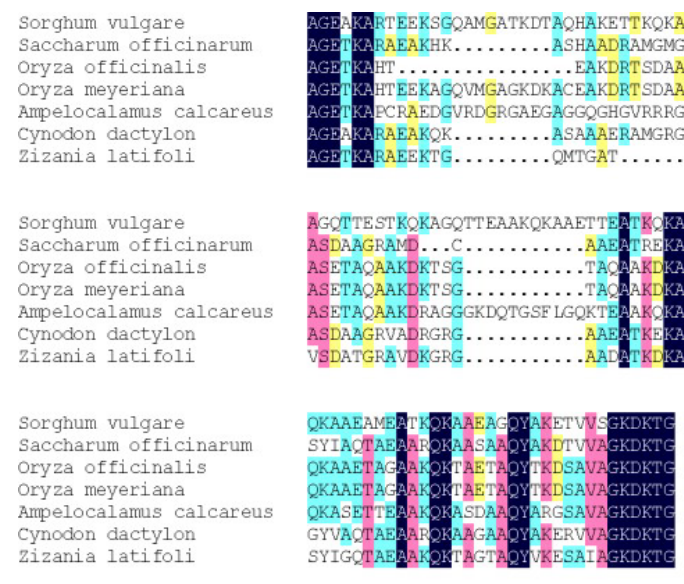

Figure 2. Sequence alignments of Group 3 LEA protein fragments of some Gramineae plants.

\section{Gene expression and regulation of LEA proteins}

Expression of the lea3 gene starts from the late period of maturation and initiation period of drying, reaches its peak in progressive dehydration, and sharply decreases after some hours of germination (Han and Kermode, 1996; Brands and David Ho, 2002). Many reports show that the expression of the lea 3 gene has no tissue-specificity, as the gene is expressed in cotyledons, panicles of seeds and also in stems, leaves and roots (vegetative tissues) (Federspiel, 2000). In this research, lea 3 genes could be expressed after seedlings or cuttings had been kept at room temperature for a few hours. Compared to the previous re- 
search, which needed treatment with appropriate concentration of $\mathrm{ABA}$ (abscisic acid), $\mathrm{NaCl}$ and PEG6000 or desiccation for several days (Shih et al., 2004), the treatment of seedlings or cuttings in this research is simpler and more convenient.

In conclusion, partial cDNA fragments of lea 3 genes from several species of the Gramineae, in which GC content is high as $77 \%$, were successfully isolated by using the simple and efficient method described in this paper. DMSO was suggested as an additive since it could remarkably increase specificity and yield of amplification. Compared to isolating genes by screening of an ABA- or other stress-responsive cDNA library, which is time-consuming and costly, this method is more convenient and economical.

\section{ACKNOWLEDGMENTS}

Research supported by the Applied Foundation Research of Yunnan Province in China (Project \#2009ZC079M) and Yunnan Province and Minister Key Subject, University Key Lab and Share Platform.

\section{REFERENCES}

Bookstein R, Lai CC, To H and Lee WH (1990). PCR-based detection of a polymorphic BamHI site in intron 1 of the human retinoblastoma (RB) gene. Nucleic Acids Res. 18: 1666.

Brands A and David Ho TH (2002). Function of a plant stress-induced gene, HVA22, synthetic enhancement screen with its yeast homology reveals its role in vesicular traffic. Plant Physiol. 130: 1121-1131.

Dure L (1993). A repeating 11-mer amino acid motif and plant desiccation. Plant J. 3: 363-369.

Federspiel N (2000). Deciphering a weed. Genomic sequencing of Arabidopsis. Plant Physiol. 124: 1456-1459.

Han B and Kermode AR (1996). Dehydrin-like proteins in castor bean seeds and seedling are differentially produced in response to ABA and water-deficit-related stresses. J. Exp. Bot. 47: 933-939.

Kawasaki ES (1990). Sample preparation from blood, cells and other fluids. In: PCR Protocols: A Guide to Methods and Applications (Innis MA, Gelfand DH, Sninsky JJ, and White TJ, eds.). Academic Press, New York, 146-152.

Kovarova M and Draber P (2000). New specificity and yield enhancer of polymerase chain reactions. Nucleic Acids Res. 28: E70.

Li M, Lin YC, Wu CC and Liu HS (2005). Enhancing the efficiency of a PCR using gold nanoparticles. Nucleic Acids Res. 33: e184.

Saiki RK, Gelfand DH, Stoffel S, Scharf SJ, et al. (1990). Formamide can dramatically improve the specificity of PCR. Nucleic Acids Res. 18: 7465.

Shih MD, Lin SC, Hsieh JS, Tsou CH, et al. (2004). Gene cloning and characterization of a soybean (Glycine max L.) LEA protein, GmPM16. Plant Mol. Biol. 56: 689-703.

Weissensteiner T and Lanchbury JS (1996). Strategy for controlling preferential amplification and avoiding false negatives in PCR typing. Biotechniques 21: 1102-1108.

Zhang LS and Zhao WM (2003). LEA protein functions to tolerance drought of the plant. Plant Physiol. Commun. 39: 61-66. 